\title{
New Bromopyrrole Alkaloids from the Marine Sponge Agelas sp.
}

Ya-Ting Sun ${ }^{1,2}$, Bin Lin ${ }^{1}$, Sheng-Ge Li ${ }^{1}$, Man Liu ${ }^{2}$, Yong-Jun Zhou ${ }^{2}$, Ying $\mathrm{Xu}^{2, *}$,

Hui-Ming Hua ${ }^{1}$ *, Hou-Wen Lin $^{2, *}$

${ }^{1}$ Key Laboratory of Structure-Based Drug Design \& Discovery, Ministry of

Education, Shenyang Pharmaceutical University, Shenyang 110016, Liaoning, P. R. China

${ }^{2}$ Marine Drugs Research Center, State Key Laboratory of Oncogenes and Related Genes, Department of Pharmacy, Ren Ji Hospital, School of Medicine, Shanghai Jiao Tong University, Shanghai 200127, China

\begin{abstract}
Chemical investigation of the marine sponge Agelas sp. collected from the South China Sea resulted in the isolation of four new dimeric bromopyrrole alkaloids, including hexazosceptrin (1) with a rare cyclohexane-fused-cyclobutane skeleton, agelestes A and B (2-3), the sceptrin analogues without any aminoimidazole substitution, and $\left(9 S, 10 R, 9^{\prime} S, 10^{\prime} R\right)$-nakamuric acid (4), of which the absolute configuration was confirmed for the first time. The structure elucidation and absolute configuration assignments were unambiguously determined via extensive spectroscopic analyses and the comparison of experimental and calculated electronic circular dichroic spectra. Compounds $\mathbf{1}$ and $\mathbf{4}$ exhibited moderate antimicrobial activity.
\end{abstract}

Keywords: marine sponge; Agelas sp.; dimeric bromopyrrole alkaloids; sceptrin

\section{Introduction}

In the light of the biodiversity and complexity of the marine environment, marine sponges have been an abundant and structurally diverse resource of bioactive metabolites. $^{1-8}$ Among these natural products, dimeric bromopyrrole alkaloids possessed intriguing structural features and significant biological activities such as

* Corresponding author.

E-mail address: xy30490@126.com (Y.X.), huimhua@163.com (H.-M.H.), franklin67@ 126.com (H.-W.L.). 
antibacterial, ${ }^{9}$ protein phosphatase type $2 \mathrm{~A}$ inhibitory, ${ }^{10}$ cytotoxic, ${ }^{11}$ and cell motility inhibitory activities, ${ }^{12}$ having attracted widespread attention of marine natural products chemists in recent decades. Sceptrin, as a representative compound, was first obtained from the sponge Agelas sceptrum in $1981,{ }^{13}$ and its absolute configuration was recently revised as $9 S, 10 R, 11 S, 9^{\prime} S, 10^{\prime} R$ through the intramolecular [2+2] cycloaddition reaction in the asymmetric syntheses, which was confirmed by the new crystal structure of natural sceptrin. ${ }^{14}$ The isolation and synthesis of this structural class have been continually investigated, resulting in a series of bromopyrrole alkaloids to date. ${ }^{15-20}$ From a biosynthetic perspective, these metabolites are proposed to be derived from clathrodin, hymenidin, and oroidin precursors by oxidation, cyclization, dimerization, and rearrangement reactions. ${ }^{21-24}$

The sponge Agelas sp. has proven to be a rich source of monomeric and dimeric bromopyrrole alkaloids, ${ }^{25-27}$ diterpene alkaloids, ${ }^{28,29}$ and glycosphingolipids. ${ }^{30}$ In our search for structurally unique and bioactive alkaloids from marine sponges collected off the Xisha Islands in the South China Sea, we have identified a series of monomeric bromopyrrole alkaloids and diterpene alkaloids from the genus Agelas, ${ }^{31,32}$ but not the dimeric bromopyrrole alkaloids. The continuing investigation on the extract derived from the sponge Agelas sp. led to the identification of four new alkaloids, a dimeric bromopyrrole alkaloid with an undescribed carbon skeleton hexazosceptrin (1), the first reported cyclobutane dimeric bromopyrrole alkaloids without any aminoimidazole ring substitution agelestes $\mathrm{A}$ and $\mathrm{B}(\mathbf{2}-\mathbf{3})$, and $(9 S, 10 R$, 9'S, 10'R)-nakamuric acid (4). Herein, the isolation, structure elucidation, absolute configuration assignments, and bioactivities of the four novel metabolites are discribed.

\section{Results and discussion}

Hexazosceptrin (1), afforded as a yellow oil, displayed the pseudo-molecular ion peaks at $m / z 633,635$, and $637(1: 2: 1)$ in ESIMS, implying the existence of two bromine atoms in the molecule. The molecular formula of $\mathbf{1}$ was found to be $\mathrm{C}_{22} \mathrm{H}_{24} \mathrm{Br}_{2} \mathrm{~N}_{10} \mathrm{O}_{3}$ by HRESIMS at $\mathrm{m} / z 633.0328[\mathrm{M}-\mathrm{H}]^{-}$, corresponding to fifteen 
degrees of unsaturation. The UV absorption at $\lambda_{\max } 268 \mathrm{~nm}$ was attributable to a substituted pyrrole chromophore. ${ }^{33}$ The IR spectrum showed the characteristic absorption band of a carbonyl group at $1686 \mathrm{~cm}^{-1}$. The ${ }^{13} \mathrm{C}$ NMR (Table 1) and DEPT data displayed 20 carbons, including three carbonyl carbons, ten olefinic carbons (four methines and six quaternary carbons), two $\mathrm{sp}^{3}$ methylenes, and five $\mathrm{sp}^{3}$ methines. These data, along with the molecular formula, highlighted the absence of two carbon signals. The presence of two 3-bromopyrrole carbonyl moieties was substantiated by the typical resonances at $\delta \mathrm{c} 97.5,113.7,122.8,127.6$, and 162.8 and $\delta \mathrm{c} 97.5,113.5$, $122.8,127.6$, and $162.9,{ }^{34}$ as well as two groups of meta-coupling aromatic protons resonated at $\delta_{\mathrm{H}} 6.90(\mathrm{~d}, J=1.5 \mathrm{~Hz}), 6.91(\mathrm{~d}, J=1.5 \mathrm{~Hz})$ and $\delta_{\mathrm{H}} 6.90(\mathrm{~d}, J=1.5 \mathrm{~Hz})$, $6.80(\mathrm{~d}, J=1.5 \mathrm{~Hz})$. In addition to the above proton signals, the ${ }^{1} \mathrm{H}$ NMR (Table 1) and HSQC spectra also revealed two amide protons, five aliphatic methines, and two aliphatic methylenes, which were connected from H-8 (H-8') to H-11 (H-10') by ${ }^{1} \mathrm{H}-{ }^{1} \mathrm{H}$ COSY spectrum (Fig. 2). Furthermore, the connectivities from $\mathrm{H}-9$ to $\mathrm{H}-9^{\prime}$, and $\mathrm{H}-10$ to $\mathrm{H}-10^{\prime}$ indicated the existence of cyclobutane as an analogue of sceptrin. ${ }^{13}$ The HMBC cross-peaks of $\mathrm{H}-8$ with $\mathrm{C}-6$, and $\mathrm{H}-8^{\prime}$ with $\mathrm{C}-6^{\prime}$ implied that two 3-bromopyrrole carbonyl moieties were attached to NH-7 and NH-7', respectively, through amide bonds. The HMBC correlations from $\mathrm{H}-10\left(\delta_{\mathrm{H}} 2.34\right)$ to $\mathrm{C}-12\left(\delta_{\mathrm{C}} 191.5\right)$ and C-11' (around $\left.\delta_{\mathrm{C}} 135.7\right)$, from $\mathrm{H}-11\left(\delta_{\mathrm{H}} 4.05\right)$ to $\mathrm{C}-12\left(\delta_{\mathrm{C}} 191.5\right), \mathrm{C}-10^{\prime}\left(\delta_{\mathrm{C}} 37.3\right)$, and $\mathrm{C}-15^{\prime}$ (around $\delta_{\mathrm{C}} 111.1$ ), from $\mathrm{H}-10^{\prime}\left(\delta_{\mathrm{H}} 2.86\right)$ to C-15', and from $\mathrm{H}-12^{\prime}\left(\delta_{\mathrm{H}} 6.29\right)$ to $\mathrm{C}-10^{\prime}, \mathrm{C}-11^{\prime}$, and $\mathrm{C}-13^{\prime} \quad\left(\delta_{\mathrm{C}}\right.$ 150.8) established aminoimidazole-fused cyclohexenone moiety, assigning $\mathrm{C}-11^{\prime}$ and $\mathrm{C}-15^{\prime}$ at around $\delta_{\mathrm{C}} 135.7$ and $\delta_{\mathrm{C}} 111.1$, respectively (Fig. 2). The remaining carbon signal at C-14 and the remaining nitrogen and hydrogen atoms in the molecular formula $\mathrm{C}_{22} \mathrm{H}_{24} \mathrm{Br}_{2} \mathrm{~N}_{10} \mathrm{O}_{3}$ suggested one guanidyl group at C-11, which was supported by the HMBC correlation of H-11 with C-14. The planar structure of $\mathbf{1}$ was thus determined as depicted. The carbon skeleton of cyclobutane fused with cyclohexanone was closely related with benzosceptrins A-C, ${ }^{9,18}$ of which a biosynthetic pathway was proposed by enzyme-catalyzed single-electron transfer from the precursor oroidin to benzosceptrin $\mathrm{C}$ with a net four-electron oxidation, ${ }^{22,35}$ and these compounds may be derived from $\mathbf{1}$ through 
cyclization and aromatization reactions.

A ROESY experiment was carried out to determine the relative stereochemistry of compound 1. The correlations of $\mathrm{H}-9 / \mathrm{H}-10^{\prime}, \mathrm{H}-11 / \mathrm{H}-9$, and $\mathrm{H}-11 / \mathrm{H}-10^{\prime}$ in the ROESY spectrum indicated their syn position, $\mathrm{H}-8 / \mathrm{H} 10, \mathrm{H}-8 / \mathrm{H}-9^{\prime}$, and $\mathrm{H}-8^{\prime} / \mathrm{H}-10^{\prime}$ as well as the large ${ }^{3} J_{\mathrm{H} 10-\mathrm{H} 11}$ values of $9.0 \mathrm{~Hz}$ suggested the trans-relationships of H-9/H-10, H-9/H-9', H-9'/H-10', H-10'/H-10, and H-10/H-11 (Fig. 2). With many attempts, crystal suitable for X-ray diffraction could not be obtained due to the oil nature, bad solubility, and instability of $\mathbf{1}$. To address the absolute configuration of $\mathbf{1}$, calculated ECD spectra were employed by the time-dependent density-functional theory (TDDFT) method at the B3LYP/6-311++G(2d, p) level with the CPCM model in methanol solution. As shown in Fig. 3, the experimental ECD spectrum was in good accordance with the calculated ECD spectrum for $\left(9 S, 10 R, 11 S, 9^{\prime} S, 10^{\prime} R\right)-1$. Therefore, the absolute configuration of 1 was consequently assigned as $9 S, 10 R, 11 S$, $9^{\prime} S, 10^{\prime} R$.

Ageleste B (2) was obtained as a yellow amorphous power. The molecular formula of $\mathrm{C}_{19} \mathrm{H}_{20} \mathrm{Br}_{2} \mathrm{~N}_{4} \mathrm{O}_{6}$ with eleven degrees of unsaturation was indicated by HRESIMS at $m / z 558.9835[\mathrm{M}+\mathrm{H}]^{+}$. The IR spectrum of 2 exhibited the characteristic absorption bands at 3250,1712 , and $1630 \mathrm{~cm}^{-1}$, indicative of carboxylic and amide carbonyl groups. The ${ }^{13} \mathrm{C}$ NMR and DEPT data in $\mathrm{C}_{5} \mathrm{D}_{5} \mathrm{~N}$ of 2 (Table 2) suggested the presence of four carbonyl carbons, eight olefinic carbons (four $\mathrm{sp}^{2}$ methines and four $\mathrm{sp}^{2}$ quaternary carbons), two $\mathrm{sp}^{3}$ methylenes, four $\mathrm{sp}^{3}$ methines, and one methoxy carbon. Analysis of its ${ }^{1} \mathrm{H},{ }^{13} \mathrm{C}$ NMR and DEPT data in $\mathrm{C}_{5} \mathrm{D}_{5} \mathrm{~N}$ (Table 2) suggested that $\mathbf{2}$ was also a dimeric bromopyrrole alkaloid with two 3-bromopyrrole amide moieties and one cyclobutane group. The correlation signals of $\mathrm{H}-8 / \mathrm{H}-9 / \mathrm{H}-10 / \mathrm{H}-10^{\prime} / \mathrm{H}-9^{\prime} / \mathrm{H}-8^{\prime}$ and $\mathrm{H}-9 / \mathrm{H}-9^{\prime}$ were observed in ${ }^{1} \mathrm{H}-{ }^{1} \mathrm{H}$ COSY spectrum. The connections of $\mathrm{C}-10$ with $\mathrm{C}-11$, and $\mathrm{C}-10^{\prime}$ with $\mathrm{C}-11^{\prime}$ were determined by the HMBC cross-peaks observed for H-9/C-11, H-10/C-11', H-9'/C-11', and H-10'/C-11 (Fig. 4). The ROESY correlations of $\mathrm{H}-9 / \mathrm{H}-10^{\prime} / \mathrm{H}-8^{\prime}$, and $\mathrm{H}-9^{\prime} / \mathrm{H}-8 / \mathrm{H}-10$ (Fig. 4), as well as the large coupling constants of $\mathrm{H}-10$ and $\mathrm{H}-10^{\prime}$ value of $10.1 \mathrm{~Hz}$ and $10.0 \mathrm{~Hz}$ respectively ${ }^{36}$ in ${ }^{1} \mathrm{H}$ NMR spectrum in DMSO- $d_{6}$ (Table 2) suggested all the trans 
relationship of the ortho-position chiral centers. The absolute configurations of compound 2 were determined as $\left(9 S, 10 R, 9^{\prime} S, 10^{\prime} R\right)$ by the close agreement between the experimental ECD spectrum for 2 and the calculated ECD spectrum for $(9 S, 10 R$, 9'S, 10'R)-2a (Fig. 5).

A positive HRESIMS ion at $\mathrm{m} / z$ 572.9991 $[\mathrm{M}+\mathrm{H}]^{+}$of ageleste $\mathrm{C}$ (3) corresponds to the molecular formula $\mathrm{C}_{20} \mathrm{H}_{22} \mathrm{Br}_{2} \mathrm{~N}_{4} \mathrm{O}_{6}$, with eleven degrees of unsaturation. The IR absorption at 1723 and $1633 \mathrm{~cm}^{-1}$ indicated the occurrence of ester and amide carbonyl groups. The ${ }^{13} \mathrm{C}$ NMR spectrum showed 10 resonance signals, suggesting 3 is a symmetrical structure. A comparison of the ${ }^{1} \mathrm{H}$ and ${ }^{13} \mathrm{C}$ NMR data (Table 2) of $\mathbf{3}$ with those of $\mathbf{2}$ revealed that $\mathbf{3}$ possessed an additional methoxyl group compared with $\mathbf{2}$, and is thus the methyl ester derivative of $\mathbf{2}$. Consideration of a likely similar biogenetic pathway, the relative configuration of $\mathbf{3}$ was reasonably assigned. The ECD spectrum (Fig. 5) and specific rotation of $\mathbf{3}$ were similar to those of $\mathbf{2}$, assigning the same absolute configurations of $\mathbf{3}$ and $\mathbf{2}$.

Compound 4 was obtained as yellow oil. The molecular formula $\mathrm{C}_{20} \mathrm{H}_{21} \mathrm{Br}_{2} \mathrm{~N}_{7} \mathrm{O}_{4}$ was deduced from the HRESIMS data $\left(\mathrm{m} / z 582.0190[\mathrm{M}+\mathrm{H}]^{+}\right)$, implying thirteen degrees of unsaturation. A comparison of ${ }^{1} \mathrm{H}$ and ${ }^{13} \mathrm{C}$ NMR data (Table 3) of 4 with those of sceptrin ${ }^{13}$ suggested that the two compounds are closely related analogues in which the only notable difference is the presence of a methyl ester moiety instead of one of the two monosubstituted 1-aminoimidazole ring systems. The HMBC cross-peaks of $\mathrm{H}-9^{\prime}$ with $\mathrm{C}-11^{\prime}$ (130.7), and $\mathrm{H}-10^{\prime}$ with $\mathrm{C}-15^{\prime}$ (109.2) implied that the reserved 1-aminoimidazole ring was located at C-10'. The all-trans relative configuration of compound 4 was determined by the correlations of $\mathrm{H}-9^{\prime} / \mathrm{H}-10, \mathrm{H}-9 / \mathrm{H}-10^{\prime}$, and $\mathrm{H}-8 / \mathrm{H}-10$ in the ROESY spectrum (Fig. 6). The planar structure and the relative configuration of this compound was thus elucidated as nakamuric acid which was first reported in 1999 without the assignment of absolute configuration. ${ }^{36}$ Subsequently, the total synthesis of $\left(9 R, 10 S, 9^{\prime} R, 10^{\prime} S\right)$-nakamuric acid was accomplished..$^{20}$ The absolute configuration of $\mathbf{4}$ was established to be $(9 S$, $10 R, 9^{\prime} S, 10^{\prime} R$ ) by comparison of the experimental and calculated ECD spectra (Fig. 7). Thus, compound 4 was proved to be an enantiomer of the synthetic one, named 
$\left(9 S, 10 R, 9^{\prime} S, 10^{\prime} R\right)$-nakamuric acid.

The isolated compounds were tested for antimicrobial activity against human pathogenic bacteria, including Escherichia coli ATCC25922, methicillin-sensitive Staphylococcus aureus ATCC25923, and methicillin-resistant S. aureus ATCC43300. Compounds 1 and $\mathbf{4}$ exhibited moderate activities against S. aureus ATCC25923 and S. aureus ATCC43300 with the same MIC value of $16 \mu \mathrm{g} / \mathrm{mL}$, while compounds 2 and $\mathbf{3}$ showed MIC values no less than $32 \mu \mathrm{g} / \mathrm{mL}$ against three pathogens. Additionally, the cytotoxicity of compounds $\mathbf{1 - 4}$ were evaluated against the histiocytic lymphoma U937 cells and human lung cancer PC9 cells, however, none of them showed significant bioactivity $\left(\mathrm{IC}_{50}\right.$ value $\left.>10 \mu \mathrm{g} / \mathrm{mL}\right)$.

Dimeric pyrrole-imidazole alkaloids have been the research hotspot in the field of chemistry since the last decade, and dozens of dimeric pyrrole-imidazole alkaloids have been discovered. However, most of their absolute stereochemistry was ambiguous or determined by total synthesis. In our research, we totally obtained four new dimeric bromopyrrole alkaloids and determined their absolute stereochemistry explicitly as $9 S, 10 R, 9^{\prime} S, 10^{\prime} R$ by comparison of experimental and calculated ECD. This result confirmed the revision of the absolute stereochemistry of sceptrin orthogonally, ${ }^{14}$ which raised the awareness of the misassigned absolute stereochemistry of the sceptrin analogs for almost 30 years. This discovery also provides the basis for the proposal of the biosynthetic pathways of these oroidin dimers.

\section{Experimental section}

\subsection{General experimental procedures.}

Optical rotation data were measured on a PerkinElmer model 341 polarimeter with a $10 \mathrm{~cm}$ length cell at $589 \mathrm{~nm}$. UV and IR $(\mathrm{KBr})$ spectra were acquired on a Hitachi U-3010 spectrophotometer and Jasco FTIR-400 spectrometer, respectively. NMR spectroscopic data were obtained on an Agilent $600 \mathrm{MHz}$ NMR instrument. HRESIMS spectra were recorded on a Waters Xevo G2-XS QTOF spectrometer. Preparative medium-pressure liquid chromatography (MPLC) was carried out on an 
Interchim Puriflash 450 Instrument. Semipreparative reversed-phased HPLC (RP-HPLC) was performed on an XBridge-Prep C18 column (Waters, $10 \times 250 \mathrm{~mm}$, $5 \mu \mathrm{m})$ with a Waters 1525 pump equipped with a 2998 photodiode array detector. The chromatographic materials included silica gel 60 (200-300 mesh; Yantai, People's Republic of China), Sephadex LH-20 (18-110 $\mu \mathrm{m}$, Pharmacia Co. Sweden), and ODS (50 $\mu \mathrm{m}$, YMC Co. Japan).

\subsection{Animal materials}

The sponge samples were collected along the coast of Yongxing Island of Xisha Islands in the South China Sea in June 2010 and identified as Agelas sp. by Prof. Jin-He Li (Institute of Oceanology, Chinese Academy of Sciences, People's Republic of China). A voucher sample (No. XS1501) was deposited at the Research Center for Marine Drugs, School of Medicine, Shanghai Jiao Tong University, People's Republic of China.

\subsection{Extraction and isolation}

The sponge (330 g, dry weight) was exhaustively extracted with ultrasound in $95 \%$ aqueous $\mathrm{EtOH}$ at room temperature over three days. After concentration under reduced pressure, the crude extract (98.3 g) was dissolved in $\mathrm{H}_{2} \mathrm{O}$ and extracted with EtOAc to afford an EtOAc-soluble fraction. The EtOAc extract was then partitioned between $90 \%$ aqueous $\mathrm{MeOH}$ and petroleum ether to afford the petroleum ether extract $(8.4 \mathrm{~g})$. Addition of $\mathrm{H}_{2} \mathrm{O}$ to the aqueous $\mathrm{MeOH}$ fraction afforded a $60 \%$ aqueous $\mathrm{MeOH}$ solution, which was extracted with $\mathrm{CH}_{2} \mathrm{Cl}_{2}$ for four times to yield 7.8 $\mathrm{g}$ of a $\mathrm{CH}_{2} \mathrm{Cl}_{2}$-soluble fraction. The $\mathrm{CH}_{2} \mathrm{Cl}_{2}$ extract was subjected to Sephadex $\mathrm{LH}-20$ column chromatography eluted with $\mathrm{CH}_{2} \mathrm{Cl}_{2}-\mathrm{MeOH}$ (1:1) to produce nine fractions A-I. LC-MS analysis of these fractions revealed that fractions E, F, and G contained compounds with molecular weights between 550 and 600 amu. Fraction G was further purified by RP-MPLC ( $\mathrm{MeCN}-\mathrm{H}_{2} \mathrm{O}, 30 \%$ to $60 \%, 150 \mathrm{~min}$, flow rate $15 \mathrm{~mL} / \mathrm{min}$ ) to give ten fractions (Fr. G1-G10). Fr. G3 was chromatographed on semipreparative RP-HPLC (Xbridge Prep C18, $3.0 \mathrm{~mL} / \mathrm{min}$ ) eluting with 24\% MeCN-0.1\% ammonia in $\mathrm{H}_{2} \mathrm{O}$ to afford compound $\mathbf{1}(20 \mathrm{mg})$. Fraction E was fractionated by RP-MPLC (MeOH- $\mathrm{H}_{2} \mathrm{O}, 20 \%$ to $80 \%, 210 \mathrm{~min}$, flow rate $20 \mathrm{~mL} / \mathrm{min}$ ) to afford seven fractions 
(Fr. E1-E7). Compounds 2 (7 mg) and 3 (3 mg) were purified from Fr. E5 and Fr. E6 using HPLC eluted with $40 \%$ and $45 \%$ MeCN-0.1\% formic acid in $\mathrm{H}_{2} \mathrm{O}$, respectively. Fraction $\mathrm{F}$ was submitted to RP-MPLC $\left(\mathrm{MeCN}-\mathrm{H}_{2} \mathrm{O}, 5 \%\right.$ to $55 \%, 150 \mathrm{~min}$, flow rate $15 \mathrm{~mL} / \mathrm{min}$ ) followed by semi-preparative RP-HPLC eluted with 35\% MeOH-0.1\% formic acid in $\mathrm{H}_{2} \mathrm{O}$ to afford 4 (20 mg).

3.3.1. Hexazosceptrin (1). Yellow oil; $[\alpha]_{\mathrm{D}}^{20}+5.7(c$ 0.2, $\mathrm{MeOH})$; UV $(\mathrm{MeOH}) \lambda_{\max }$ (log $\varepsilon) 204$ (3.0), 223 (2.4), 268 (2.5) nm; IR (film) $v_{\max }$ 3281, 2925, 1628, 1567, 1525, $1385,1325,1265,1224,1121,919,656,601 \mathrm{~cm}^{-1}$; ECD $(0.32 \mathrm{mM}, \mathrm{MeOH}) \lambda_{\max }(\Delta \varepsilon)$ $242.0(+13.43), 278.5(-8.04) \mathrm{nm} ;{ }^{1} \mathrm{H}$ and ${ }^{13} \mathrm{C}$ NMR data, Table 1; HRESIMS $\mathrm{m} / \mathrm{z}$ 633.0328 [M - H] $]^{-}$(calcd. for $\mathrm{C}_{22} \mathrm{H}_{23} \mathrm{Br}_{2} \mathrm{~N}_{10} \mathrm{O}_{3}, 633.0321$ ).

3.3.2. Ageleste B (2). Yellow amorphous powder; $[\alpha]_{\mathrm{D}}^{20}-18$ (c $\left.0.18, \mathrm{MeOH}\right)$; UV $(\mathrm{MeOH}) \lambda_{\max }(\log \varepsilon) 215(2.0), 268(2.3) \mathrm{nm} ; \mathrm{ECD}(0.20 \mathrm{mM}, \mathrm{MeOH}) \lambda_{\max }(\Delta \varepsilon) 213.5$ (+8.43), 237.5 (-4.29), 256.5 (+6.46), 278.0 (-17.46) nm; IR (film) $v_{\max } 3250,3130$, 2926, 2856, 1712, 1630, 1568, 1527, 1432, 1387, 1328, 1224, 1129, 921, 827, 771, $602 \mathrm{~cm}^{-1} ;{ }^{1} \mathrm{H}$ and ${ }^{13} \mathrm{C}$ NMR data, Table 2; HRESIMS $\mathrm{m} / z 558.9835[\mathrm{M}+\mathrm{H}]^{+}$(calcd. for $\mathrm{C}_{19} \mathrm{H}_{21} \mathrm{Br}_{2} \mathrm{~N}_{4} \mathrm{O}_{6}, 558.9828$ ).

3.3.3. Ageleste $C$ (3). Yellow amorphous powder; $[\alpha]_{\mathrm{D}}^{20}-16(c 0.20, \mathrm{MeOH})$; UV $(\mathrm{MeOH}) \lambda_{\max }(\log \varepsilon) 216(1.8), 268(2.2) \mathrm{nm} ; \mathrm{ECD}(0.34 \mathrm{mM}, \mathrm{MeOH}) \lambda_{\max }(\Delta \varepsilon) 213.0$ (+12.90), 237.0 (-4.35), $256.0(+5.50), 278.5$ (-18.68) nm; IR vmax 3243, 2925, 2854, 1723, 1633, 1566, 1524, 1435, 1386, 1325, 1218, 1127, 919, 829, 768, 599 $\mathrm{cm}^{-1} ;{ }^{1} \mathrm{H}$ and ${ }^{13} \mathrm{C}$ NMR data, Table 2; HRESIMS $\mathrm{m} / z$ 572.9991 $[\mathrm{M}+\mathrm{H}]^{+}$(calcd. for $\mathrm{C}_{20} \mathrm{H}_{23} \mathrm{Br}_{2} \mathrm{~N}_{4} \mathrm{O}_{6}$, 572.9984).

3.3.4. (9S, 10R, 9'S, 10'R)-Nakamuric acid (4). Yellow oil; $[\alpha]_{\mathrm{D}}^{20}-42(c 0.15, \mathrm{MeOH})$; UV $(\mathrm{MeOH}) \lambda_{\max }(\log \varepsilon) 268(1.7) \mathrm{nm}$; ECD $(0.28 \mathrm{mM}, \mathrm{MeOH}) \lambda_{\max }(\Delta \varepsilon) 233.5$ (-16.93), 281 (-6.01) nm; IR $v_{\max } 3254,2972,2931,1682,1624,1567,1527,1387$, 1329, 1226, 1131, 921, 772, $600 \mathrm{~cm}^{-1}$; ${ }^{1} \mathrm{H}$ and ${ }^{13} \mathrm{C}$ NMR data, Table 3 ; HRESIMS $\mathrm{m} / z$ 582.0109 $[\mathrm{M}+\mathrm{H}]^{+}$(calcd. for $\mathrm{C}_{20} \mathrm{H}_{22} \mathrm{Br}_{2} \mathrm{~N}_{7} \mathrm{O}_{4}, 582.0100$ ).

\subsection{Biological assays}

3.4.1. Antibacterial Activity Assay. The antibacterial activities of the isolated compounds against three different bacteria ( $S$. aureus ATCC25923, 
methicillin-resistant S. aureus (MRSA) ATCC43300, and E. coli ATCC25922) were evaluated in 96-well microplates according to a previously reported protocol. ${ }^{37}$ Chloramphenicol was used as the positive control with MICs of 4,8 , and $4 \mu \mathrm{g} / \mathrm{mL}$, respectively.

3.4.2. Cytotoxicity Assay. The cytotoxicity assay of four compounds against the human cancer U937 and PC9 cell lines was performed by MTT method, ${ }^{38}$ using doxorubicin as a positive control with $\mathrm{IC}_{50}$ values of 0.05 and $0.22 \mu \mathrm{M}$, respectively.

\subsection{Theoretical ECD Calculations}

Conformational search was carried out by CONFLEX using molecular mechanics MMFF94s for compound 1, 2, and 4, each of which gave 100 conformers. The low-energy conformers of the compounds separately accounting for more than $1 \%$ Boltzmann distribution was further optimized successively in the gas phase by semi-empirical method and the Hartree-Fork (HF) method at the 6-31G (d) level in Gaussian 09 program package. Further optimizition using the density functional theory (DFT) at the B3LYP/6-31G (d,p) level in gas phase and in the same way in the methanol resulted in no imaginary frequencies. Solvent effects were taken into consideration by using the conductor polarizable continuum model (CPCM). The conformers were calculated for their electronic circular dichroism (ECD) by the time-dependent density functional theory (TD-DFT) method at the B3LYP/6-311++G (2d,p) level with the CPCM model in methanol solution. The overall calculated ECD curves were generated by Boltzmann weighting of their selected low-energy conformers using the software SpecDis. ${ }^{39}$

Acknowledgments: This research was supported by National Science Foundation of China (NO. 41406139, 81225023, U1605221).

Supplementary Materials: The followings are available online, HRESIMS, 1D and 2D NMR data of compounds $\mathbf{l}-\mathbf{4}$. 
Table 1. ${ }^{1} \mathrm{H}$ and ${ }^{13} \mathrm{C}$ NMR spectroscopic data of compound $\mathbf{1}$

\begin{tabular}{|c|c|c|c|c|}
\hline & $\mathrm{CD}_{3} \mathrm{OD}$ & & DMSO- $d_{6}$ & \\
\hline & $\delta_{\mathrm{H}}($ mult, $J$ in $\mathrm{Hz})$ & $\delta_{\mathrm{C}}($ type $)$ & $\delta_{\mathrm{H}}(\mathrm{mult}, J$ in $\mathrm{Hz})$ & $\delta_{\mathrm{C}}($ type $)$ \\
\hline 1 & & & 11.80, brs & \\
\hline 2 & $6.90, \mathrm{dd}(4.0,1.5)$ & $122.8(\mathrm{CH})$ & $6.95, \mathrm{dd}(4.0,1.4)$ & $121.0(\mathrm{CH})$ \\
\hline 3 & & $97.5(\mathrm{C})$ & & $95.0(\mathrm{C})$ \\
\hline 4 & $6.91, \mathrm{~d}(1.5)$ & $113.7(\mathrm{CH})$ & $6.99, \mathrm{~d}(1.4)$ & $111.4(\mathrm{CH})$ \\
\hline 5 & & $127.6(\mathrm{C})$ & & $127.0(\mathrm{C})$ \\
\hline 6 & & $162.8(\mathrm{C})$ & & $159.6(\mathrm{C})$ \\
\hline 7 & & & $8.73, \mathrm{~m}$ & \\
\hline 8 & $3.54, \mathrm{~m} \quad 3.40, \mathrm{~m}$ & $43.6\left(\mathrm{CH}_{2}\right)$ & $3.56, \mathrm{~m} \quad 3.10, \mathrm{~m}$ & $42.5\left(\mathrm{CH}_{2}\right)$ \\
\hline 9 & $2.13, \mathrm{~m}$ & $40.9(\mathrm{CH})$ & $2.13, \mathrm{~m}$ & $40.2(\mathrm{CH})$ \\
\hline 10 & $2.34, \mathrm{~m}$ & $45.4(\mathrm{CH})$ & $1.77, \mathrm{~m}$ & $46.2(\mathrm{CH})$ \\
\hline 11 & $4.05, \mathrm{~d}(9.0)$ & $64.5(\mathrm{CH})$ & $3.82, \mathrm{~d}(9.0)$ & $65.0(\mathrm{CH})$ \\
\hline 12 & & $191.5(\mathrm{C})$ & & $190.3(\mathrm{C})$ \\
\hline 14 & & $172.8(\mathrm{C})$ & & $172.5(\mathrm{C})$ \\
\hline $1^{\prime}$ & & & 11.80, brs & \\
\hline $2^{\prime}$ & $6.90, \mathrm{dd}(4.0,1.5)$ & $122.8(\mathrm{CH})$ & $6.95, \mathrm{dd}(4.0,1.4)$ & $121.1(\mathrm{CH})$ \\
\hline $3^{\prime}$ & & $97.5(\mathrm{C})$ & & $95.0(\mathrm{C})$ \\
\hline $4^{\prime}$ & $6.80, \mathrm{~d}(1.5)$ & $113.5(\mathrm{CH})$ & $6.88, \mathrm{~d}(1.4)$ & $111.4(\mathrm{CH})$ \\
\hline $5^{\prime}$ & & $127.6(\mathrm{C})$ & & $127.0(\mathrm{C})$ \\
\hline $6^{\prime}$ & & $162.9(\mathrm{C})$ & & $159.9(\mathrm{C})$ \\
\hline $7^{\prime}$ & & & $8.40, \mathrm{t}(5.3)$ & \\
\hline $8^{\prime}$ & $3.42, \mathrm{~m} \quad 3.45, \mathrm{~m}$ & $43.1\left(\mathrm{CH}_{2}\right)$ & $3.36, \mathrm{~m}(2 \mathrm{H})$ & $41.8\left(\mathrm{CH}_{2}\right)$ \\
\hline $9^{\prime}$ & $2.18, \mathrm{~m}$ & $44.9(\mathrm{CH})$ & $2.12, \mathrm{~m}$ & $41.2(\mathrm{CH})$ \\
\hline $10^{\prime}$ & 2.86, t-like (9.0) & $37.3(\mathrm{CH})$ & 2.72, t-like $(9.0)$ & $\mathrm{b}(39.3)(\mathrm{CH})$ \\
\hline $11^{\prime}$ & & $\mathrm{a}(135.7)(\mathrm{C})$ & & $\mathrm{a}$ \\
\hline $12^{\prime}$ & $6.29, \mathrm{~s}$ & & $6.18, \mathrm{~s}$ & \\
\hline $13^{\prime}$ & & $150.8(\mathrm{C})$ & & $149.2(\mathrm{C})$ \\
\hline $15^{\prime}$ & & $\mathrm{a}(111.1)(\mathrm{C})$ & & $\mathrm{a}$ \\
\hline
\end{tabular}

a No signal was observed in ${ }^{13} \mathrm{C}$ NMR spectrum. The chemical shift was established by the HMBC cross-peak.

b Overlapped with a signal of DMSO- $d_{6}$. 
Table 2. ${ }^{1} \mathrm{H}$ and ${ }^{13} \mathrm{C}$ NMR spectroscopic data of compounds 2 and $\mathbf{3}$ (in $\mathrm{C}_{5} \mathrm{D}_{5} \mathrm{~N}$ )

\begin{tabular}{|c|c|c|c|c|c|}
\hline \multirow{2}{*}{ Position } & \multicolumn{3}{|c|}{2} & \multicolumn{2}{|c|}{3} \\
\hline & $\delta_{\mathrm{H}}\left(\mathrm{DMSO}-d_{6}\right)$ & $\delta_{\mathrm{H}}\left(\mathrm{C}_{5} \mathrm{D}_{5} \mathrm{~N}\right)$ & $\delta$ c (type) & $\delta_{\mathrm{H}}(J$ in $\mathrm{Hz})$ & $\delta \mathrm{c}$ (type) \\
\hline 1 & $11.81, \mathrm{~s}$ & $13.53, \mathrm{~s}$ & & $13.58, \mathrm{~s}$ & \\
\hline 2 & 6.97, br s & $7.35, \mathrm{~s}$ & $122.6(\mathrm{CH})$ & $7.37, \mathrm{~s}$ & $122.7(\mathrm{CH})$ \\
\hline 3 & & & $97.0(\mathrm{C})$ & & $97.0(\mathrm{C})$ \\
\hline 4 & 6.84, br s & $7.41, \mathrm{~s}$ & $112.7(\mathrm{CH})$ & $7.38, \mathrm{~s}$ & $112.7(\mathrm{CH})$ \\
\hline 5 & & & $128.6(\mathrm{C})$ & & $128.6(\mathrm{C})$ \\
\hline 6 & & & $162.1(\mathrm{C})$ & & $162.2(\mathrm{C})$ \\
\hline 7 & 8.43, br s & 9.18, br s & & 9.12 , br s & \\
\hline 8 & $\mathrm{a}$ & $3.89, \mathrm{~m}(2 \mathrm{H})$ & $43.4\left(\mathrm{CH}_{2}\right)$ & $3.68, \mathrm{~m} \quad 3.87, \mathrm{~m}$ & $42.8\left(\mathrm{CH}_{2}\right)$ \\
\hline 9 & $2.27, \mathrm{~m}$ & $2.85, \mathrm{~m}$ & $41.2(\mathrm{CH})$ & $2.71, \mathrm{~m}$ & $41.0(\mathrm{CH})$ \\
\hline 10 & $2.84, \mathrm{t}(10.1)$ & $3.52, \mathrm{~m}$ & $42.9(\mathrm{CH})$ & $3.41, \mathrm{~m}$ & $41.5(\mathrm{CH})$ \\
\hline 11 & & & $176.0(\mathrm{C})$ & & $173.4(\mathrm{C})$ \\
\hline 12 & & & & $3.47, \mathrm{~s}(3 \mathrm{H})$ & $52.1\left(\mathrm{CH}_{3}\right)$ \\
\hline $1^{\prime}$ & $11.82, \mathrm{~s}$ & $13.53, \mathrm{~s}$ & & $13.58, \mathrm{~s}$ & \\
\hline $2^{\prime}$ & 6.97, br s & $7.35, \mathrm{~s}$ & $122.5(\mathrm{CH})$ & $7.37, \mathrm{~s}$ & $122.7(\mathrm{CH})$ \\
\hline $3^{\prime}$ & & & $97.0(\mathrm{C})$ & & $97.0(\mathrm{C})$ \\
\hline $4^{\prime}$ & 6.84, br s & $7.41, \mathrm{~s}$ & $112.7(\mathrm{CH})$ & $7.38, \mathrm{~s}$ & $112.7(\mathrm{CH})$ \\
\hline $5^{\prime}$ & & & $128.7(\mathrm{C})$ & & $128.6(\mathrm{C})$ \\
\hline $6^{\prime}$ & & & $162.2(\mathrm{C})$ & & $162.2(\mathrm{C})$ \\
\hline $7^{\prime}$ & 8.20, br s & 9.17 , br s & & 9.12 , br s & \\
\hline $8^{\prime}$ & $\mathrm{a}$ & $3.72, \mathrm{~s} \quad 3.90, \mathrm{~s}$ & $43.0\left(\mathrm{CH}_{2}\right)$ & $3.68, \mathrm{~m} \quad 3.87, \mathrm{~m}$ & $42.8\left(\mathrm{CH}_{2}\right)$ \\
\hline $9^{\prime}$ & $2.27, \mathrm{~m}$ & $2.75, \mathrm{~m}$ & $41.0(\mathrm{CH})$ & $2.71, \mathrm{~m}$ & $41.0(\mathrm{CH})$ \\
\hline $10^{\prime}$ & $2.93, \mathrm{t}(10.0)$ & $3.56, \mathrm{~m}$ & $42.0(\mathrm{CH})$ & $3.41, \mathrm{~m}$ & $41.5(\mathrm{CH})$ \\
\hline $11^{\prime}$ & & & $174.0(\mathrm{C})$ & & $173.4(\mathrm{C})$ \\
\hline $12^{\prime}$ & $3.52, \mathrm{~s}(3 \mathrm{H})$ & $3.50, \mathrm{~s}(3 \mathrm{H})$ & $52.1\left(\mathrm{CH}_{3}\right)$ & $3.47, \mathrm{~s}(3 \mathrm{H})$ & $52.1\left(\mathrm{CH}_{3}\right)$ \\
\hline
\end{tabular}

a Overlapped with a signal of HDO 
Table 3. ${ }^{1} \mathrm{H}$ and ${ }^{13} \mathrm{C}$ NMR spectroscopic data of compound 4 (in $\mathrm{CD}_{3} \mathrm{OD}$ )

\begin{tabular}{cll}
\hline Position & \multicolumn{1}{c}{$\delta_{\mathrm{H}}$ mult, $(\mathrm{J}$ in Hz) } & \multicolumn{1}{c}{ c (type) } \\
\hline 2 & & \\
\hline 3 & $6.80, \mathrm{~d}(0.9)$ & $122.9(\mathrm{CH})$ \\
4 & & $97.7(\mathrm{C})$ \\
5 & $6.76, \mathrm{~d}(0.9)$ & $113.7(\mathrm{CH})$ \\
6 & & $127.7(\mathrm{C})$ \\
8 & & $162.8(\mathrm{C})$ \\
9 & $3.26, \mathrm{~m} 3.55, \mathrm{~m}$ & $44.6\left(\mathrm{CH}_{2}\right)$ \\
10 & $2.32, \mathrm{~m}$ & $41.8(\mathrm{CH})$ \\
11 & $2.58, \mathrm{t}(10.0)$ & $50.2(\mathrm{CH})$ \\
$2^{\prime}$ & & $181.6(\mathrm{C})$ \\
$3^{\prime}$ & $6.81, \mathrm{~d}(1.0)$ & $123.0(\mathrm{CH})$ \\
$4^{\prime}$ & & $97.7(\mathrm{C})$ \\
$5^{\prime}$ & $6.71, \mathrm{~d}(1.0)$ & $113.7(\mathrm{CH})$ \\
$6^{\prime}$ & & $127.5(\mathrm{C})$ \\
$8^{\prime}$ & & $163.0(\mathrm{C})$ \\
$9^{\prime}$ & $3.36, \mathrm{~m}(2 \mathrm{H})$ & $42.7(\mathrm{CH})$ \\
$10^{\prime}$ & $2.12, \mathrm{~m}$ & $43.2(\mathrm{CH})$ \\
$11^{\prime}$ & $3.04, \mathrm{t}(10.0)$ & $36.6(\mathrm{CH})$ \\
$13^{\prime}$ & & $130.7(\mathrm{C})$ \\
$15^{\prime}$ & & $148.9(\mathrm{C})$ \\
& $6.37, \mathrm{~s}$ & $109.2(\mathrm{CH})$ \\
\hline
\end{tabular}




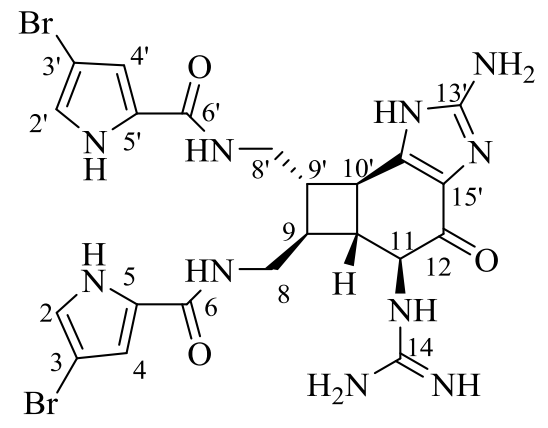

1

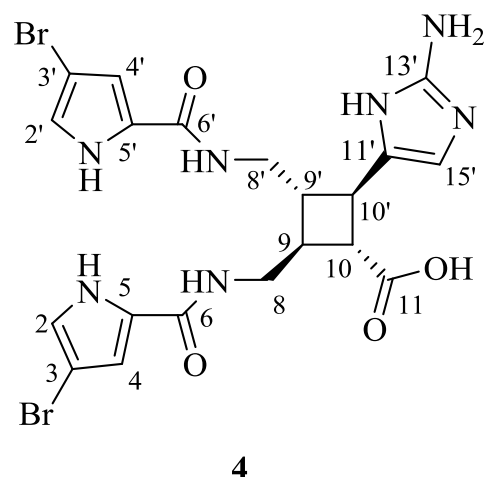

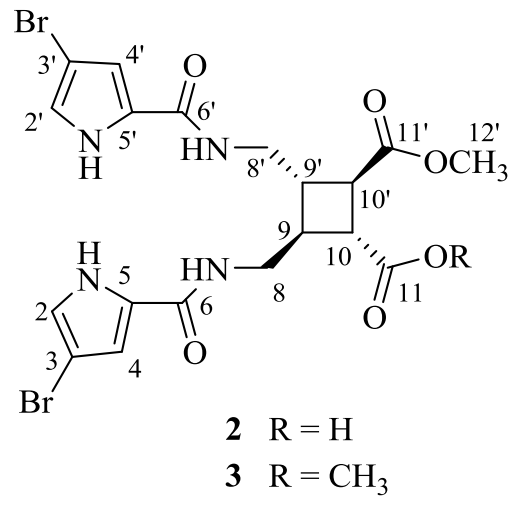

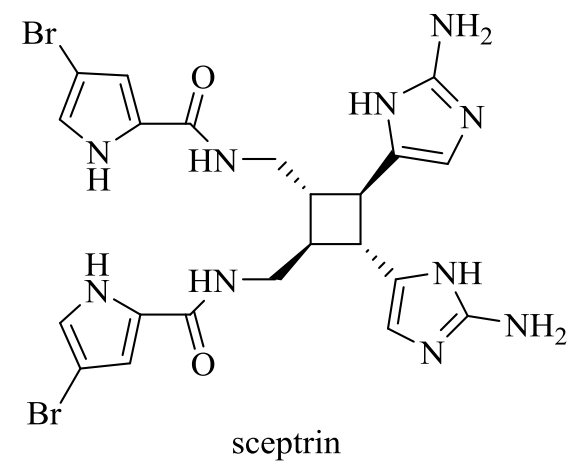

Fig. 1 The structures of compounds 1-4
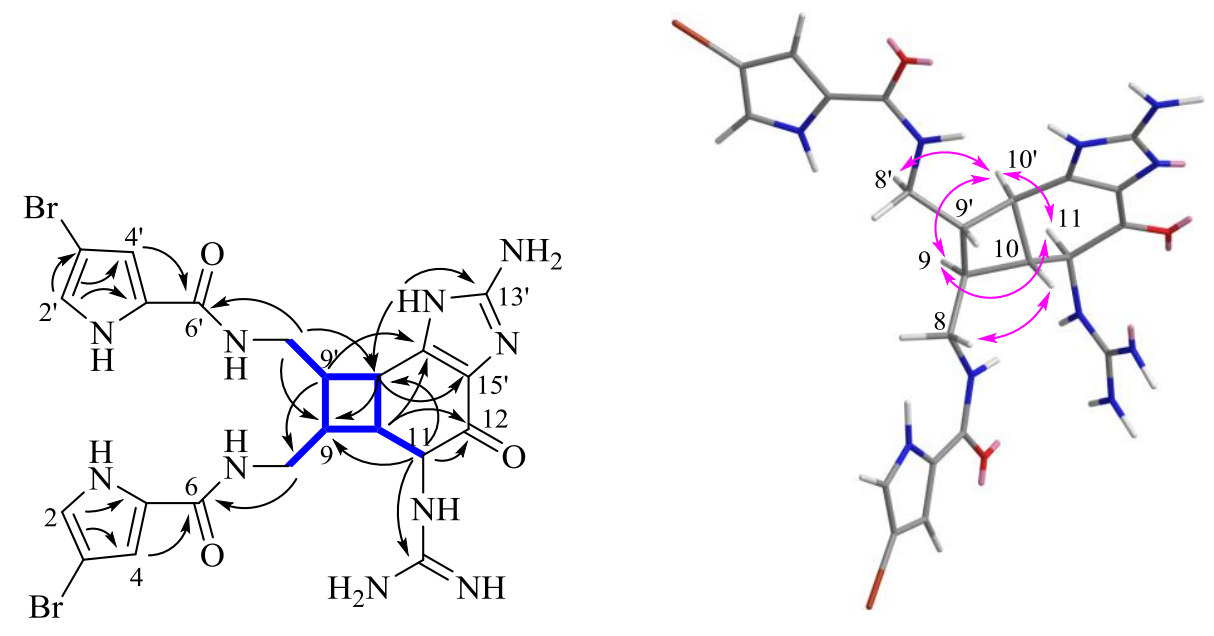

- $\operatorname{COSY} \frown \mathrm{HMBC}$

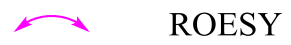

Fig. 2 Key HMBC, COSY, and ROESY correlations of compound 1 


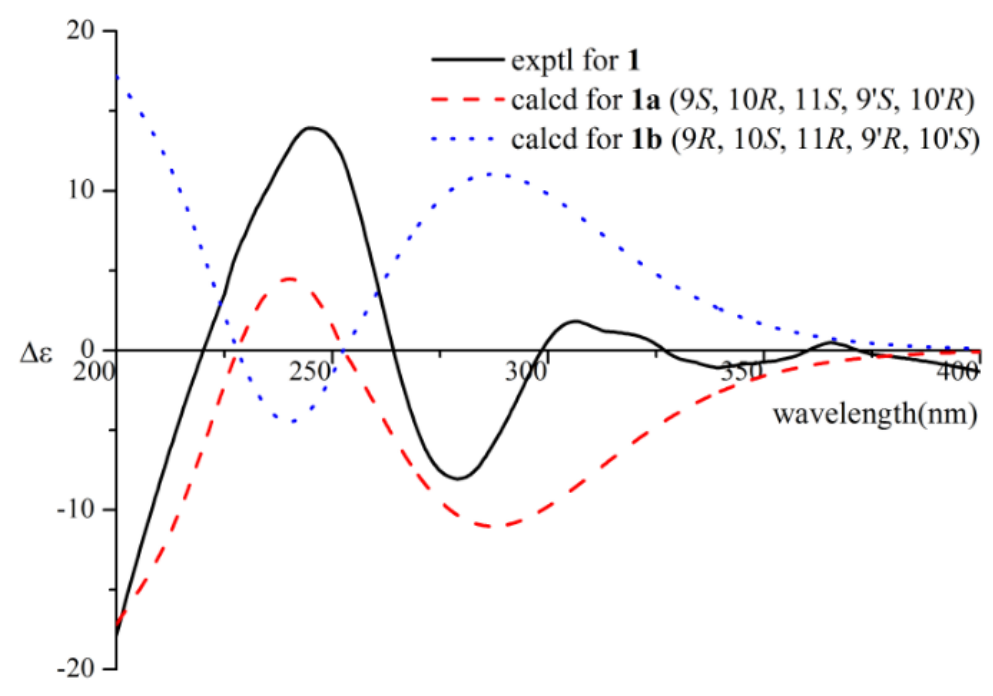

Fig. 3 Experimental and calculated ECD spectra of 1
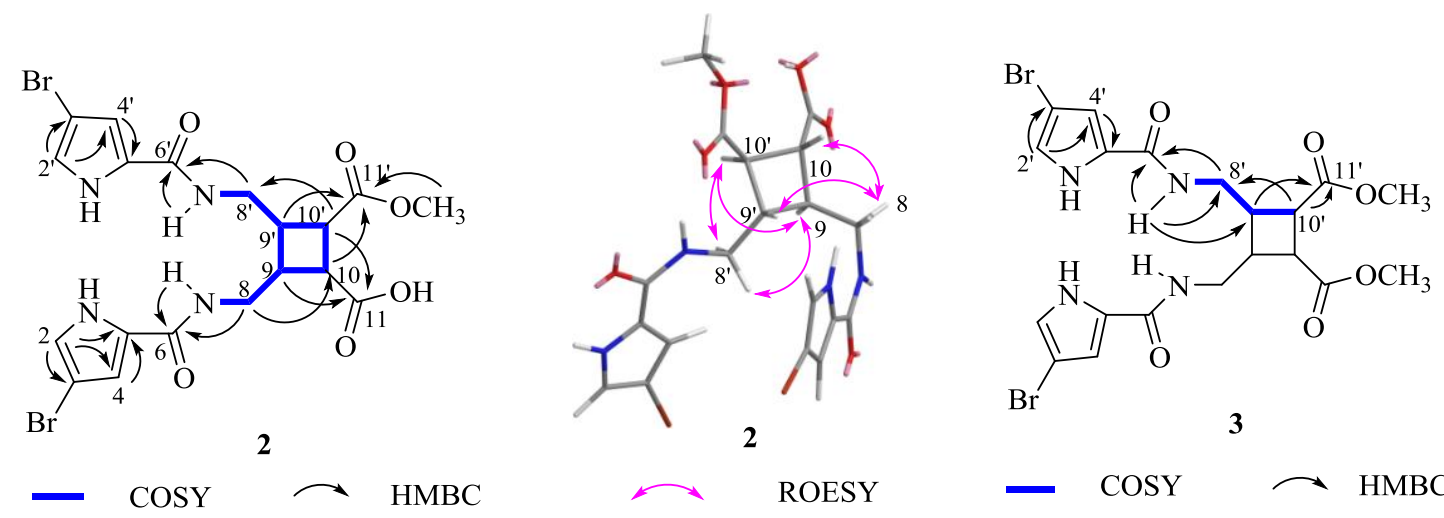

Fig. 4 Key HMBC and COSY correlations of compounds $\mathbf{2}$ and $\mathbf{3}$, and ROESY correlations of $\mathbf{2}$

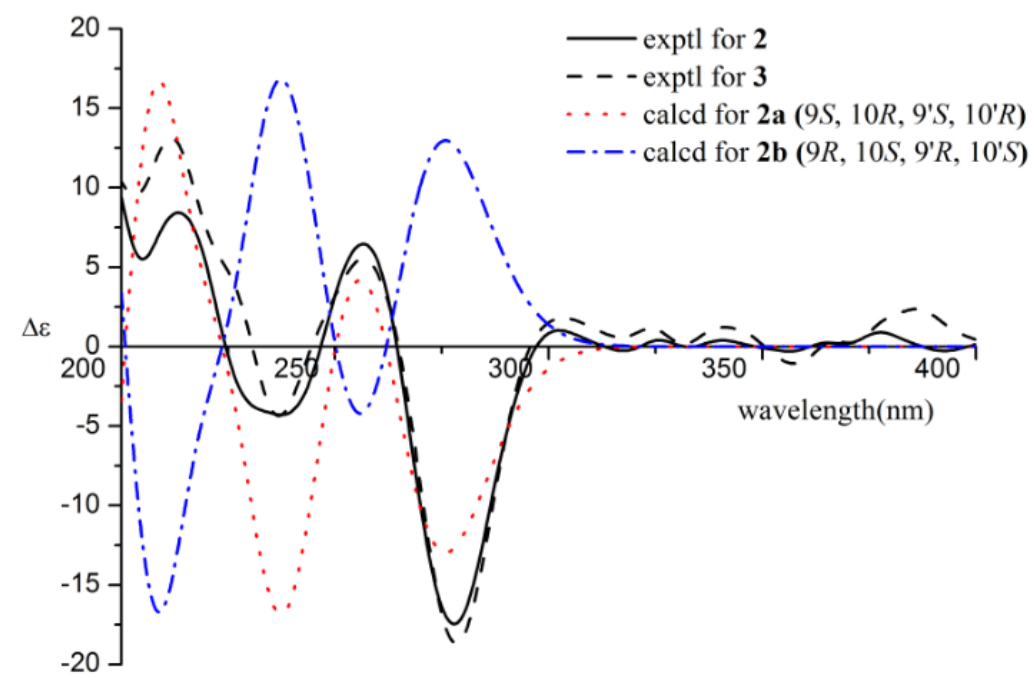

Fig. 5 Experimental and calculated ECD spectra of compounds $\mathbf{2}$ and $\mathbf{3}$ 

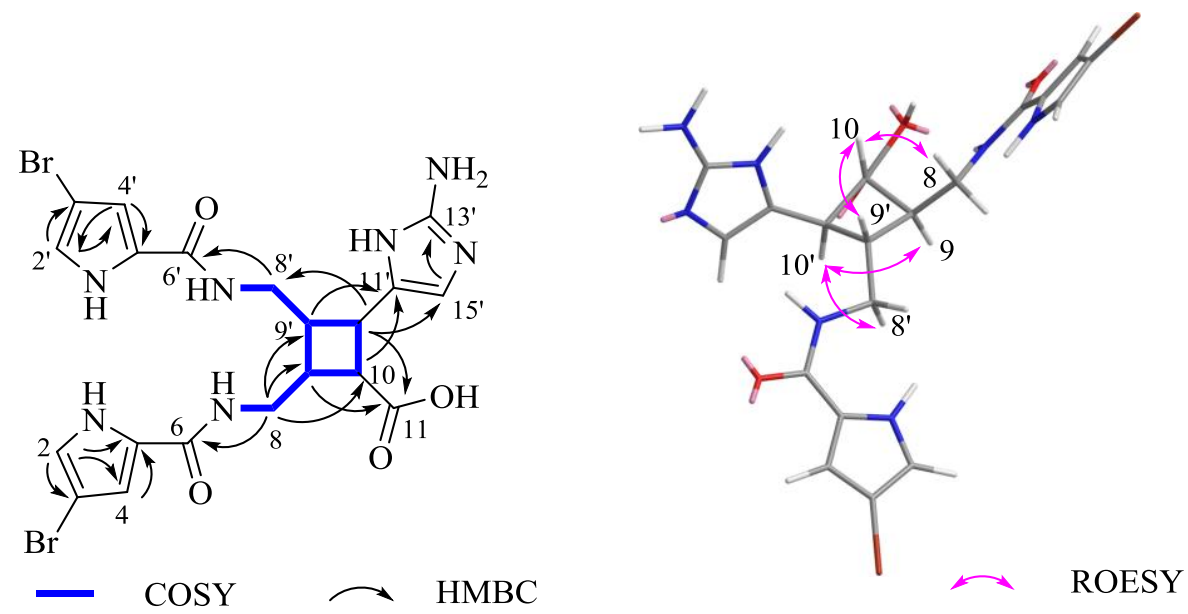

Fig.6 Key HMBC, COSY, and ROESY correlations of compound 4

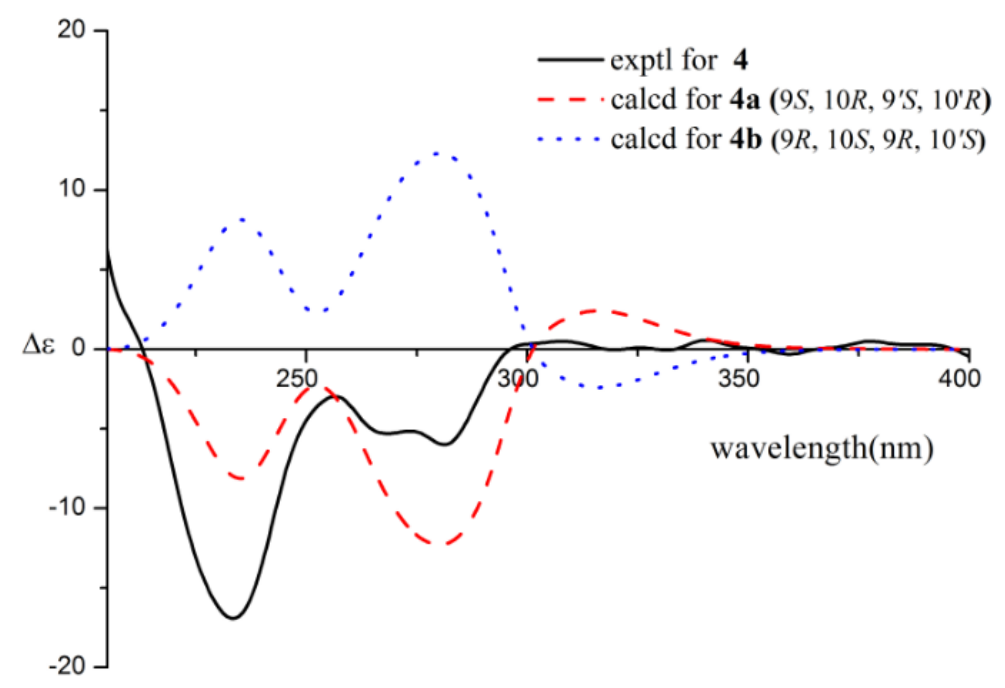

Fig.7 Experimental and calculated ECD spectra of 4

\section{References}

1. Blunt, J.W.; Copp, B.R.; Keyzers, R.A.; Munro, M.H.; Prinsep, M.R. Marine natural products. Nat. Prod. Rep. 2016, 33, 382-431.

2. Alghazwi, M.; Qi Kan, Y.; Zhang, W.; Ping Gai, W.; Yan, X.-X. Neuroprotective activities of marine natural products from marine sponges. Curr. Med. Chem. 2016, 23, 360-382.

3. Keyzers, R.A.; Davies-Coleman, M.T. Anti-inflammatory metabolites from marine sponges. Chem. Soc. Rev. 2005, 34, 355-365. 
4. Aoki, S.; Watanabe, Y.; Sanagawa, M.; Setiawan, A.; Kotoku, N.; Kobayashi, M. Cortistatins A, B, C, and D, anti-angiogenic steroidal alkaloids, from the marine sponge Corticium simplex. J. Am. Chem. Soc. 2006, 128, 3148-3149.

5. Buchanan, M.S.; Carroll, A.R.; Addepalli, R.; Avery, V.M.; Hooper, J.N.A.; Quinn, R.J. Psammaplysenes C and D, cytotoxic alkaloids from Psammoclemma sp. J. Nat. Prod. 2007, 70, 1827-1829.

6. Yamada, M.; Takahashi, Y.; Kubota, T.; Fromont, J.; Ishiyama, A.; Otoguro, K.; Yamada, H.; Ōmura, S.; Kobayashi, J.i. Zamamidine C, 3,4-dihydro-6-hydroxy-10,11-epoxymanzamine A, and 3,4-dihydromanzamine $\mathrm{J} N$-oxide, new manzamine alkaloids from sponge Amphimedon sp. Tetrahedron 2009, 65, 2313-2317.

7. Fan, G.T.; Li, Z.L.; Shen, S.; Zeng, Y.; Yang, Y.S.; Xu, M.J.; Bruhn, T.; Bruhn, H.; Morschhäuser, J.; Bringmann, G.; et al. Baculiferins A-O, O-sulfated pyrrole alkaloids with anti-HIV-1 activity, from the chinese marine sponge Iotrochota baculifera. Bioorg. Med. Chem. 2010, 18, 5466-5474.

8. Liang, Z.B.; Sulzmaier, F.J.; Yoshida, W.Y.; Kelly, M.; Ramos, J.W.; Williams, P.G. Neopetrocyclamines A and B, polycyclic diamine alkaloids from the sponge Neopetrosia cf exigua. J. Nat. Prod. 2015, 78, 543-547.

9. Kubota, T.; Araki, A.; Yasuda, T.; Tsuda, M.; Fromont, J.; Aoyama, K.; Mikami, Y.; Wälchli, M.R.; Kobayashi, J.i. Benzosceptrin C, a new dimeric bromopyrrole alkaloid from sponge Agelas sp. Tetrahedron Lett. 2009, 50, 7268-7270.

10. Endo, T.; Tsuda, M.; Okada, T.; Mitsuhashi, S.; Shima, H.; Kikuchi, K.; Mikami, Y.; Fromont, J.; Kobayashi, J.i. Nagelamides A-H, new dimeric bromopyrrole alkaloids from marine sponge Agelas species. J. Nat. Prod. 2004, 67, 1262-1267.

11. Tilvi, S.; Moriou, C.; Martin, M.-T.; Gallard, J.-F.; Sorres, J.; Patel, K.; Petek, S.; Debitus, C.; Ermolenko, L.; Al-Mourabit, A. Agelastatin E, agelastatin F, and benzosceptrin C from the marine sponge Agelas dendromorpha. J. Nat. Prod. 2010, 73, 720-723.

12. Cipres, A.; O’Malley, D.P.; Li, K.; Finlay, D.; Baran, P.S.; Vuori, K. Sceptrin, a marine natural compound, inhibits cell motility in a variety of cancer cell lines. ACS Chem. Biol. 2010, 5, 195-202.

13. Walker, R.P.; Faulkner, D.J.; Van Engen, D.; Clardy, J. Sceptrin, an antimicrobial agent from the sponge Agelas sceptrum. J. Am. Chem. Soc. 1981, 103, 6772-6773.

14. Ma, Z.Q.; Wang, X.L.; Wang, X.; Rodriguez, R.A.; Moore, C.E.; Gao, S.H.; Tan, X.H.; Ma, Y.Y.; Rheingold, A.L.; Baran, P.S.; et al. Asymmetric syntheses of sceptrin and massadine and evidence for biosynthetic enantiodivergence. Science 2014, 346, 219-224.

15. Baran, P.S.; Zografos, A.L.; O'Malley, D.P. Short total synthesis of ( \pm )-sceptrin. J. Am. Chem. Soc. 2004, 126, 3726-3727.

16. Birman, V.B.; Jiang, X.-T. Synthesis of sceptrin alkaloids. Org. Lett. 2004, 6, 2369-2371.

17. Shen, X.Y.; Perry, T.L.; Dunbar, C.D.; Kelly-Borges, M.; Hamann, M.T. Debromosceptrin, an alkaloid from the caribbean sponge Agelas conifera. J. Nat. Prod. 1998, 61, 1302-1303.

18. Appenzeller, J.; Tilvi, S.; Martin, M.T.; Gallard, J.F.; El-Bitar, H.; Dau, E.T.H.; Debitus, C.; Laurent, D.; Moriou, C.; Al-Mourabit, A. Benzosceptrins A and B with a unique benzocyclobutane skeleton and nagelamide $\mathrm{S}$ and $\mathrm{T}$ from Pacific sponges. Org. lett. 2009, 
11, 4874-4877.

19. Munoz, J.; Kock, M. Hybrid pyrrole-imidazole alkaloids from the sponge Agelas sceptrum. J. Nat. Prod. 2016, 79, 434-437.

20. O'Malley, D.P.; Li, K.; Maue, M.; Zografos, A.L.; Baran, P.S. Total synthesis of dimeric pyrrole-imidazole alkaloids: Sceptrin, ageliferin, nagelamide E, oxysceptrin, nakamuric acid, and the axinellamine carbon skeleton. J. Am. Chem. Soc. 2007, 129, 4762-4775.

21. Genta-Jouve, G.; Cachet, N.; Holderith, S.; Oberhansli, F.; Teyssie, J.L.; Jeffree, R.; Al Mourabit, A.; Thomas, O.P. New insight into marine alkaloid metabolic pathways: Revisiting oroidin biosynthesis. Chembiochem 2011, 12, 2298-2301.

22. Stout, E.P.; Wang, Y.G.; Romo, D.; Molinski, T.F. Pyrrole aminoimidazole alkaloid metabiosynthesis with marine sponges Agelas conifera and Stylissa caribica. Angew. Chem. Int. Ed. 2012, 51, 4877-4881.

23. Wang, X.; Ma, Z.; Wang, X.; De, S.; Ma, Y.; Chen, C. Dimeric pyrrole-imidazole alkaloids: Synthetic approaches and biosynthetic hypotheses. Chem. Commun. 2014, 50, 8628-8639.

24. Al-Mourabit, A.; Zancanella, M.A.; Tilvi, S.; Romo, D. Biosynthesis, asymmetric synthesis, and pharmacology, including cellular targets, of the pyrrole-2-aminoimidazole marine alkaloids. Nat. Prod. Rep. 2011, 28, 1229-1260.

25. Yasuda, T.; Araki, A.; Kubota, T.; Ito, J.; Mikami, Y.; Fromont, J.; Kobayashi, J.i. Bromopyrrole alkaloids from marine sponges of the genus Agelas. J. Nat. Prod. 2009, 72, 488-491.

26. Scala, F.; Fattorusso, E.; Menna, M.; Taglialatela-Scafati, O.; Tierney, M.; Kaiser, M.; Tasdemir, D. Bromopyrrole alkaloids as lead compounds against protozoan parasites. Mar. Drugs 2010, 8, 2162-2174.

27. Kusama, T.; Tanaka, N.; Takahashi-Nakaguchi, A.; Gonoi, T.; Fromont, J.; Kobayashi, J.i. Bromopyrrole alkaloids from a marine sponge Agelas sp. Chem. Pharm. Bull. 2014, 62, 499-503.

28. Fu, X.; Schmitz, F.J.; Tanner, R.S.; Kelly-Borges, M. Agelasines H and I, 9-methyladenine-containing diterpenoids from an Agelas sponge. J. Nat. Prod. 1998, 61, 548-550.

29. Appenzeller, J.; Mihci, G.; Martin, M.T.; Gallard, J.F.; Menou, J.L.; Boury-Esnault, N.; Hooper, J.; Petek, S.; Chevalley, S.; Valentin, A.; et al. Agelasines J, K, and L from the solomon islands marine sponge Agelas cf. mauritiana. J. Nat. Prod. 2008, 71, 1451-1454.

30. Costantino, V.; Fattorusso, E.; Imperatore, C.; Mangoni, A. Glycolipids from sponges. Part 17. Clathrosides and isoclathrosides, unique glycolipids from the caribbean sponge Agelas clathrodes. J. Nat. Prod. 2006, 69, 73-78.

31. Yang, F.; Hamann, M.T.; Zou, Y.; Zhang, M.Y.; Gong, X.B.; Xiao, J.R.; Chen, W.S.; Lin, H.W. Antimicrobial metabolites from the paracel islands sponge Agelas mauritiana. J. Nat. Prod. 2012, 75, 774-778.

32. Zhu, Y.; Wang, Y.; Gu, B.B.; Yang, F.; Jiao, W.H.; Hu, G.H.; Yu, H.B.; Han, B.N.; Zhang, W.; Shen, Y.; et al. Antifungal bromopyrrole alkaloids from the south China sea sponge Agelas sp. Tetrahedron 2016, 72, 2964-2971.

33. Garcia, E.E.; Benjamin, L.E.; Fryer, R.I. Reinvestigation into the structure of oroidin, a bromopyrrole derivative from marine sponge. J. Chem. Soc., Chem. Commun. 1973, 
78-79.

34. Keifer, P.A.; Schwartz, R.E.; Koker, M.E.; Hughes Jr, R.G.; Rittschof, D.; Rinehart, K.L. Bioactive bromopyrrole metabolites from the caribbean sponge Agelas conifera. J. Org. Chem. 1991, 56, 2965-2975.

35. Stout, E.P.; Morinaka, B.I.; Wang, Y.G.; Romo, D.; Molinski, T.F. De novo synthesis of benzosceptrin $\mathrm{C}$ and nagelamide $\mathrm{H}$ from $7-{ }^{15} \mathrm{~N}$-oroidin: Implications for pyrrole-aminoimidazole alkaloid biosynthesis. J. Nat. Prod. 2012, 75, 527-530.

36. Eder, C.; Proksch, P.; Wray, V.; van Soest, R.W.; Ferdinandus, E.; Pattisina, L.A.; Sudarsono. New bromopyrrole alkaloids from the indopacific sponge Agelas nakamurai. J. Nat. Prod. 1999, 62, 1295-1297.

37. Ding, L.J.; Gu, B.B.; Jiao, W.H.; Yuan, W.; Li, Y.X.; Tang, W.Z.; Yu, H.B.; Liao, X.J.; Han, B.N.; Li, Z.Y.; et al. New furan and cyclopentenone derivatives from the sponge-associated fungus Hypocrea koningii PF04. Mar. Drugs 2015, 13, 5579-5592.

38. Jiao, W.H.; Xu, T.T.; Yu, H.B.; Chen, G.D.; Huang, X.J.; Yang, F.; Li, Y.S.; Han, B.N.; Liu, X.Y.; Lin, H.W. Dysideanones A-C, unusual sesquiterpene quinones from the south China sea sponge Dysidea avara. J. Nat. Prod. 2014, 77, 346-350.

39. Bruhn, T.; Schaumloffel, A.; Hemberger, Y.; Bringmann, G. SpecDis: Quantifying the comparison of calculated and experimental electronic circular dichroism spectra. Chirality 2013, 25, 243-249. 


\section{Graphical Abstract}

New Bromopyrrole Alkaloids from the
Marine Sponge Agelas sp.
Ya-Ting Sun ${ }^{1,2}$, Bin Lin ${ }^{1}$, Sheng-Ge $\mathbf{L i}^{1}$, Man $\mathbf{L i u}^{2}$, Yong-Jun Zhou', Ying $\mathbf{X u}^{2, *}$, Hui-Ming Hua ${ }^{1, *}$, Hou-
Wen Lin ${ }^{2} *$
${ }^{1}$ Key Laboratory of Structure-Based Drug Design \& Discovery, Ministry of Education, Shenyang
Pharmaceutical University, Shenyang 110016, Liaoning, P. R. China
Marine Drugs Research Center, State Key Laboratory of Oncogenes and Related Genes, Department of

